\title{
ROLA KONTRAKTACJI W AKTYWIZACJI LOKALNEGO RYNKU PRACY
}

\begin{abstract}
Streszczenie. W artykule wyjaśniono istotę kontraktacji w aktywizacji lokalnych rynków pracy w Polsce. Wskazano pozytywne i negatywne skutki dla instytucjonalnej obsługi rynku pracy, które może ona powodować. Podstawę rozważań stanowiły krytyczne studia aktów prawnych regulujących proces kontraktacji w obszarze rynku pracy i studia dostępnej literatury przedmiotu. Opisany model kontraktacji należy traktować jako otwarty, będzie on ewoluował na skutek rezultatów, w zakresie aktywizacji osób bezrobotnych.

Słowa kluczowe: kontraktacja, publiczna służba zatrudnienia, prywatne agencje zatrudnienia, rynek pracy.
\end{abstract}

\section{WPROWADZENIE}

Procesy zachodzące na rynku pracy cechuje dynamizm, co powoduje, że sytuacja wielu podmiotów na nim funkcjonujących ulega zmianie i to implikuje konieczność uruchomienia działań mających na celu udzielenie im odpowiedniego wsparcia. Pomocy potrzebują bezrobotni, którzy na skutek dokonujących się zmian w gospodarce tracą pracę lub to, że nie pracują wynika $\mathrm{z}$ faktu wygaśnięcia odpowiedniej umowy, która była podstawą ich zatrudnienia. Pomocy oczekują również pracodawcy, którzy nie mogą znaleźć kandydatów do pracy, a utrzymujące się wakaty oznaczają dla nich konkretne straty.

Praktyka pokazuje, że publiczne instytucje rynku pracy, które powinny zapewnić realizację usług na ich rzecz, nie są w stanie im pomóc. Przyczyn tego stanu jest wiele, najczęściej jednak wskazuje się na niewystarczające zasoby kadrowe, a co się z tym wiąże - krótki czas obsługi poszczególnych grup klientów lub ograniczony dostęp do określonych usług i instrumentów rynku pracy (Wóycicka i in. 2008; Kukulak-Dolata 2007; The Service 2000). Problemy te dostrzegane są $\mathrm{w}$ różnych opracowaniach i dokumentach strategicznych, $\mathrm{z}$ treści których wynika, że publiczne służby zatrudnienia (PSZ) nie są w stanie samodzielnie rozwiązać problemów ujawniających się na rynku pracy, dlatego muszą w ramach prowadzonej polityki rynku pracy tworzyć warunki dla partnerstwa.

\footnotetext{
* Uniwersytet Łódzki, Wydział Ekonomiczno-Socjologiczny, Katedra Polityki Ekonomicznej, doiwona@uni.lodz.pl
} 
Problem ten znajduje odzwierciedlenie w zasadniczym dokumencie regulującym funkcjonowanie publicznych służb zatrudnienia (czyli organów zatrudnienia takich jak marszałek województwa i starosta, w imieniu których odpowiednie działania prowadzą Wojewódzkie Urzędy Pracy i Powiatowe Urzędy Pracy), tj. w Ustawie z dnia 20 kwietnia 2004 r. o promocji zatrudnienia i instytucjach rynku pracy (dalej jako: ustawa o promocji zatrudnienia). Wyznacza ona grupy kompetencji w sferze sterowania rynkiem pracy, które są przypisane regionalnym i lokalnym instytucjom, będącym zarówno podmiotami publicznymi, jak i niepublicznymi. Dzięki takiemu podejściu, w ramach polityki rynku pracy, stworzono tzw. quasi-rynki, na których podmioty kupujące usługi aktywizacyjne (czyli PSZ) nie są ich konsumentami, gdyż są nimi osoby bezrobotne, a konsumenci nie mają swobodnego wyboru usług oferowanych przez rynek. Ponadto, w tym segmencie rynku, niepubliczne agencje zatrudnienia świadczą usługi pośrednictwa pracy i doradztwa zawodowego równolegle z PSZ na warunkach zbliżonych do wolnej konkurencji.

W opisywanym przypadku występuje rodzaj prywatyzacji funkcjonalnej, która zakłada częściowe przekazanie podmiotom niepublicznym realizacji określonych działań przy jednoczesnym zachowaniu kompetencji instytucji publicznych i odpowiedzialności za ich wykonanie i finansowanie. Organy administracji publicznej nie mogą pozbyć się odpowiedzialności za przypisane im ustawowo zadania, nie mogą też zmieniać ich zakresu lub rezygnować $\mathrm{z}$ ich wykonania, ale mogą zlecić realizację zadań instytucjom zewnętrznym w ramach kontraktu.

$\mathrm{W}$ artykule podjęto próbę analizy i oceny modelu kontraktacji w obszarze aktywizacji lokalnych rynków pracy. Wynikiem jej powinno być zdefiniowanie szans i zagrożeń, jakie generuje kontraktacja w kontekście instytucjonalnej obsługi rynku pracy. Analizowany model należy traktować jako otwarty, a jego kształt będzie ewoluował na skutek doświadczeń wynikających z osiąganych rezultatów, a także opinii podmiotów uczestniczących w kontraktacji i tych, którzy byli odbiorcami usług.

W artykule teoretyczną podstawę rozważań stanowiły krytyczne studia obowiązujących aktów prawnych oraz dostępnej literatury przedmiotu. W pierwszym przypadku uwagę skierowano na rozwiązania - w zakresie kontraktacji zaproponowane przez państwo w Ustawie o zmianie ustawy o promocji zatrudnienia i instytucjach rynku pracy oraz niektórych innych ustaw z dnia 14 marca 2014 r. (Dz.U. 2014. poz. 598), w drugim uwzględniono literaturę krajową i zagraniczną w celu wskazania kontekstu, zakresu kontraktacji oraz przedstawienia wyników kontraktacji innych państw. Analiza literatury i aktów umożliwiła zdefiniowanie form i cech przyjętej koncepcji kontraktacji działań w zakresie aktywizacji rynku pracy. 


\section{ISTOTA KONTRAKTACJI}

W Polsce kontraktacja początkowo interpretowana była jako umowa, która odnosiła się do skupu produktów rolnych (Stownik wyrazów obcych 1995: 592). $\mathrm{Z}$ upływem czasu, a przede wszystkim rozwoju poszczególnych segmentów rynku, zakres tego pojęcia uległ rozszerzeniu. Termin ten coraz częściej pojawiał się w obszarze polityki społecznej, co było związane z próbą poprawy jakości zarządzania $\mathrm{w}$ sektorze publicznym m.in. poprzez wprowadzenie do niego elementów z NPM.

Marek Rymsza definiuje kontraktowanie jako zlecanie realizacji usług publicznych podmiotom niepaństwowym przez administrację rządową i samorządową w ramach umów kontraktowych (Rymsza 2013). Rola kontraktacji w aktywizacji lokalnych rynków pracy może być istotna i wynikać z relacji między PSZ a innymi instytucjami rynku pracy. Relacje te mogą przybierać formę współpracy na przykład w zakresie wymiany informacji na temat podmiotów rynku pracy mogą też oznaczać komplementarność działań wykonywanych na rzecz obsługi pracodawców, bezrobotnych czy osób poszukujących zatrudnienia.

$\mathrm{Z}$ powyższych rozważań wynika, że kontraktacja działań, jakie mogą być podejmowane w obszarze rynku pracy, a których celem jest jego aktywizacja, może prowadzić do rozwoju kooperacji między poszczególnymi instytucjami. Należy dodać, iż tendencje ku współpracy i partnerskim rozwiązaniom pojawiły się w polskiej praktyce m.in. jako skutek wytycznych Komisji Europejskiej dotyczących pozyskiwania funduszów pomocowych UE i ponadsektorowego kreowania lokalnych i regionalnych strategii rozwoju. Partnerstwa te z pionierskich przeistaczały się w trwałą strukturę współpracy, efektem której były dobre projekty. Nie powstałyby one, gdyby nie dyfuzja potencjałów instytucji/organizacji tworzących i realizujących projekty (Krzyszkowski, Marks 2006: 19 i nast.). Natomiast w przypadku usług rynku pracy kontraktacja najwcześniej stosowana była przez PSZ do zlecania instytucjom zewnętrznym organizacji szkoleń.

Od 2009 r. zlecanie usług dotyczyło również usługi pośrednictwa pracy; niestety w praktyce nie odnotowano prowadzenia działań w tym obszarze. Obserwowano natomiast współpracę, jaka pojawiała się między PUP a agencjami zatrudnienia realizującymi usługi pracy tymczasowej. Opierała się ona na kierowaniu bezrobotnych przez PUP do agencji, mającej możliwość doraźnego ich zatrudnienia.

W 2014 r. wprowadzono kolejne zmiany w przepisach prawnych, które umożliwiły upowszechnienie i rozszerzenie kontraktacji w obszarze instytucjonalnej obsługi rynku pracy i one będą przedmiotem szczegółowej analizy w prezentowanym opracowaniu. 


\section{FORMY KONTRAKTACJI I JEJ UCZESTNICY}

Podstawy instytucjonalne/prawne kontraktacji różnych działań, których celem jest obsługa podmiotów rynku pracy, określone są w ustawie o promocji zatrudnienia i instytucjach rynku pracy (Dz.U. 2014. poz. 598). Istotne są jej trzy różne artykuły ${ }^{1}, \mathrm{z}$ których każdy określa inny podmiot i przedmiot kontraktu. Kontraktacja w tych przypadkach oznacza wykonywanie różnych świadczeń dotyczących obsługi rynku pracy przez instytucje niepubliczne na podstawie umowy, która jest formą delegowania uprawnień (Baron-Wiaterek 2008: 119). Zjawisko to oznacza prywatyzację zadań i zmiany w organizacji rynku pracy, które dokonują się $\mathrm{w}$ wyniku odpowiednich upoważnień przydzielonych w tym zakresie marszałkowi województwa i staroście. Powierzenie zadań publicznych innym instytucjom następuje $\mathrm{w}$ wyniku przekazania przez organy publiczne kompetencji władczych.

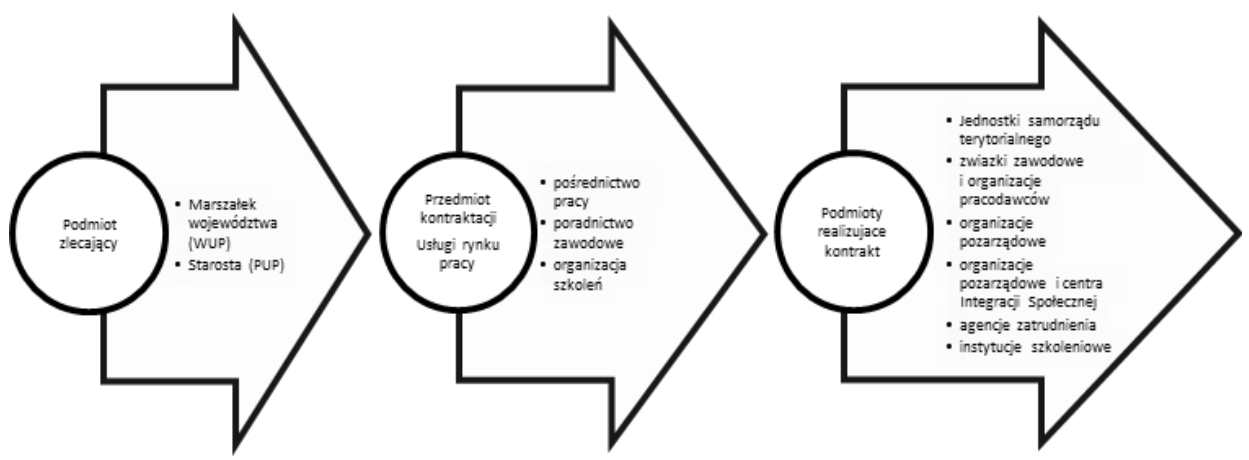

Rysunek 1. Kontraktacja usług rynku pracy - podmiot i przedmiot kontraktacji

Źródło: opracowanie własne.

Problem przekazywania uprawnień dotyczy między innymi realizacji usług rynku pracy, czyli pośrednictwa pracy, doradztwa zawodowego, organizacji szkoleń (Rysunek 1). Organem delegującym zadania może być marszałek województwa lub starosta, natomiast realizatorem ich siedem różnych instytucji. Mogą to być podmioty pochodzące $\mathrm{z}$ różnych sektorów, np. $\mathrm{z}$ sektora publicznego (jak jednostki samorządu terytorialnego), sektora pozarządowego (jak związki zawodowe, organizacje pozarządowe statutowo zajmujące się problematyką rynku pracy, organizacje pracodawców, Centra Integracji Społecznej) czy nawet z sektora prywatnego, reprezentowanego przez instytucje szkoleniowe i agencje zatrudnienia. W tym przypadku organ zlecający przeprowadza otwarty konkurs

\footnotetext{
${ }^{1} \mathrm{~W}$ tym przypadku należy mieć na uwadze artykuły $24,61 \mathrm{~b}, 66 \mathrm{~d}$. wyżej wymienionej ustawy.
} 
ofert na zasadach i w trybie określonym w przepisach o działalności pożytku publicznego i o wolontariacie (Dz.U. 2010, poz. 1536) lub zarządza zakup tych usług na zasadach i w trybie określonym w przepisach o zamówieniach publicznych (Dz.U. 2014, poz. 12320). Na podstawie powyższych zapisów można stwierdzić, iż w Polsce zostały stworzone podstawy prywatyzacji i uspołecznienia usług rynku pracy w kierunku rozwiązań wielosektorowych, określanych w literaturze przedmiotu jako welfare mix (Grewiński 2009).

Praktyka kontraktacji, jak już wspomniano, od dawna była obserwowana w zakresie organizacji szkoleń, ale patrząc na wymierne rezultaty działań prowadzonych w tym obszarze, można je ocenić negatywnie ${ }^{2}$ (Błędowski 2008: 130 i nast.). Chodzi tu o ich niską efektywność, spowodowaną trybem zamówień, opierającym się na przetargach publicznych, w których decydującym kryterium okazuje się cena, a nie jakość realizowanych szkoleń. Problem ten dotyczy szkoleń finansowanych z Funduszu Pracy czy z Europejskiego Funduszu Społecznego. W przypadku tego drugiego źródła finansowania niska efektywność mierzona odsetkiem uczestników szkoleń powracających do zasobu pracujących w określonym czasie była zastępowana wskaźnikiem, informującym o skali oddziaływania szkoleń na rzeczywistość mierzoną liczbą osób przeszkolonych (Rymsza 2013: 292), co ostatecznie powodowało ich wysoką ocenę i uzasadniało wysokie koszty stałe dla tego typu usługi.

Uwzględnienie, jako przedmiotu kontraktu, dwóch kolejnych usług pośrednictwa i doradztwa można uznać za uzasadnione w sytuacji, kiedy analizuje się wskaźniki obciążenia pośredników i doradców zawodowych, liczone liczbą bezrobotnych przypadających na jednego pracownika PUP. Są one bardzo wysokie, co szczególnie widoczne jest w przypadku doradców zawodowych (Informacje o stanie zatrudnienia...). Implikuje to ograniczony dostęp do usługi doradztwa, która wydaje się mieć fundamentalne znaczenie dla wielu kategorii bezrobotnych - szczególnie tych, którzy mają trudności nie tylko z wejściem do zasobu pracujących, ale i z utrzymaniem się w nim. Problem ten wydaje się jeszcze bardziej nasilony, gdy rozpatruje się go w kontekście zmian organizacyjnych, jakie wprowadzono w polskich urzędach pracy po 27 maja 2014 r. Chodzi o powołanie stanowiska doradcy klienta, które niejednokrotnie jest obsadzane doradcami zawodowymi. Oprócz nich rolę taką pełnią pośrednicy pracy czy specjaliści do spraw rozwoju zawodowego. Wskazane zmiany, zdaniem doradców zawodowych, spowodowały, że doradztwo w klasycznej formule zostało usunięte z usług świadczonych przez urzędy pracy (Jak zniszczono... 2015), co

${ }^{2}$ Oceny takie są dokładnie opisane w raportach wydawanych przez Ministerstwo Pracy i Polityki Społecznej nt. Efektywność podstawowych form aktywizacji zawodowej realizowanych w ramach programów na rzecz promocji zatrudnienia, tagodzenia skutków bezrobocia i aktywizacji zawodowej (http://www.praca. gov.pl). 
może generować potrzebę wypełnienia powstałej luki przez działalność innych instytucji rynku pracy w ramach kontraktowania.

Bardzo rzadko natomiast w praktyce urzędy zlecają na zewnątrz realizację usługi pośrednictwa pracy. Należy dodać, iż możliwości takie pojawiły się w wyniku nowelizacji ustawy o promocji zatrudnienia w 2009 r., ale nie były one wykorzystywane. Przyczyna tego stanu może wynikać z obawy urzędów przed redukcją zatrudnienia w sytuacji kiedy pozbyłyby się realizacji podstawowej - i historycznie ujmując - najstarszej funkcji.

Regulacja kontraktacji w kolejnych artykułach wspomnianej ustawy o promocji zatrudnienia jest pełniejsza ze względu na fakt wprowadzenia do umów kryterium skuteczności działań podejmowanych przez instytucje realizujące kontrakt i wskazania osób, które mogą być objęte przedmiotem kontraktu.

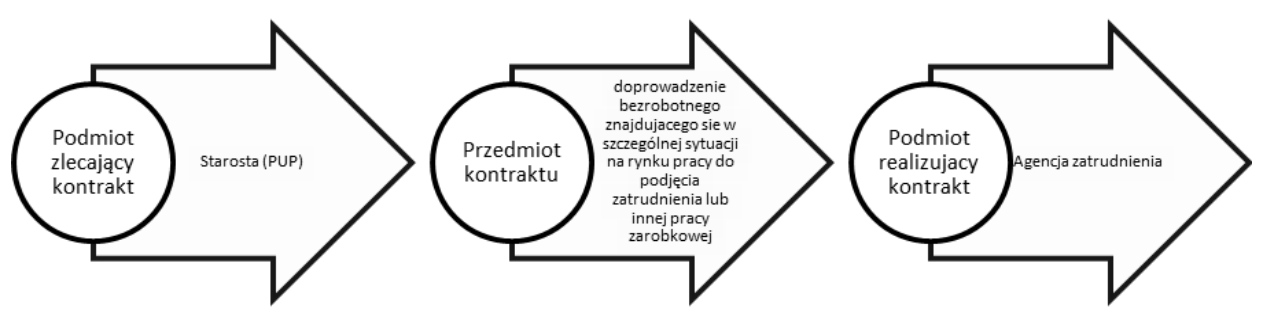

Rysunek 2. Kontraktacja dotycząca doprowadzenia bezrobotnego będącego w szczególnej sytuacji do zatrudnienia

Źródło: opracowanie własne.

I tak w przypadku artykuł 66b (Dz.U. 2014, poz. 598) wymienionej wyżej ustawy działania, których celem jest doprowadzenie ściśle określonych osób posiadających status bezrobotnego do zasobu pracujących, są wynikiem decyzji, którą podejmuje starosta na wniosek PUP (Rysunek 2). Beneficjentami działań objętych kontraktem są osoby będące w szczególnej sytuacji na rynku pracy, czyli: bezrobotni do 30 roku życia i powyżej 50 roku życia, osoby długotrwale bezrobotne, bezrobotni niepełnosprawni, bezrobotni korzystający ze świadczeń pomocy społecznej, bezrobotni posiadający co najmniej jedno dziecko do 6 roku życia lub co najmniej jedno dziecko niepełnosprawne do 18 roku życia. Agencja otrzymuje wynagrodzenie za zrealizowaną usługę pod warunkiem, że osoby, których dotyczy kontrakt, będą zatrudnione lub będą wykonywały pracę zarobkową na podstawie umów cywilno-prawnych przez okres 6 miesięcy. Wysokość opłaty za zaktywizowanie jednego bezrobotnego nie może przekroczyć $150 \%$ przeciętnego wynagrodzenia, obowiązującego w dniu zawarcia umowy. Rozlicze- 
nie za wykonaną usługę przewidziano w dwóch transzach. Pierwsza może być zrealizowana w dniu zawarcia umowy i jej wartość nie może przekraczać $30 \%$ łącznej kwoty środków przewidzianych w umowie, zaś druga - nazwijmy ją motywacyjną - jest wypłacona po spełnieniu warunku zatrudnienia osoby przez okres 6 miesięcy. Ustawodawca określił również zasady zwrotu środków w sytuacji, kiedy bezrobotny nie spełnił warunku podjęcia zatrudnienia lub innej pracy zarobkowej na podstawie umów cywilno-prawnych we wskazanym wyżej okresie. Pozytywnie w tym przypadku należy ocenić fakt uwzględnienia w umowie skutku działań podejmowanych przez wykonawcę, co oznacza, iż bierze się pod uwagę w umowie tzw. kryteria efektywnościowe. Efektem w tym przypadku jest wykonywanie pracy przez beneficjenta przez okres co najmniej 6 miesięcy.

Najszerzej problem kontraktacji został przedstawiony w tzw. rozdziale 13 ustawy o promocji zatrudnienia, a dotyczy on zlecania działań aktywizacyjnych instytucjom zewnętrznym przez marszałka województwa, w imieniu którego odpowiednie działania prowadzi wojewódzki urząd pracy (Rysunek 3). Za działania aktywizacyjne przyjmuje się pakiet działań mających na celu podjęcie i utrzymanie przez bezrobotnego odpowiedniej pracy lub działalności gospodarczej. Przyjęcie takiej interpretacji działań aktywizacyjnych należy ocenić pozytywnie, bowiem daje ona możliwość podejmowania inicjatyw, które mogą okazać się innowacyjne w świetle dotychczas stosowanych praktyk. Daje ona możliwość łączenia różnych usług i instrumentów rynku pracy, które umożliwią beneficjentom nie tylko wejście na rynek pracy, ale i utrzymanie się na nim. W ten sposób istnieje możliwość uruchamiania działań, które nie są przewidziane zapisami ustawy o promocji zatrudnienia i instytucjach rynku pracy, a które mogą okazać się uzasadnione i konieczne ze względu na sytuację, jaka jest na lokalnym rynku pracy czy cechy osobowościowo zawodowe osób objętych wsparciem. Zatem zastosowany pakiet działań aktywizacyjnych implikować będzie wyjściem poza ramy usług i instrumentów, które są najczęściej stosowane i wyeliminuje pewien schematyzm w obsłudze instytucjonalnej rynku pracy.

Racjonalność czy optymalizacja działań aktywizacyjnych powinna wynikać zatem ze swobody, jaką posiadają realizatorzy kontraktu w doborze instrumentów i usług, ale może o niej również decydować sposób ich wynagradzania. Agencja zatrudnienia może za jednego aktywizowanego bezrobotnego otrzymać gratyfikację w wysokości maksymalnie trzykrotnego przeciętnego wynagrodzenia obowiązującego w dniu zawarcia umowy o świadczenie działań aktywizacyjnych. Ostatecznie wysokość wynagrodzenia będzie determinowana okresem wykonywania pracy przez osobę objętą kontraktem. Wynagrodzenie dla agencji składa się z dwóch części, stałej i ruchomej, które będą wypłacane w czterech transzach w następujących proporcjach: $20 \% ; 20 \% ; 30 \% ; 30 \%$ wynagrodzenia brutto (Rysunek 4). 


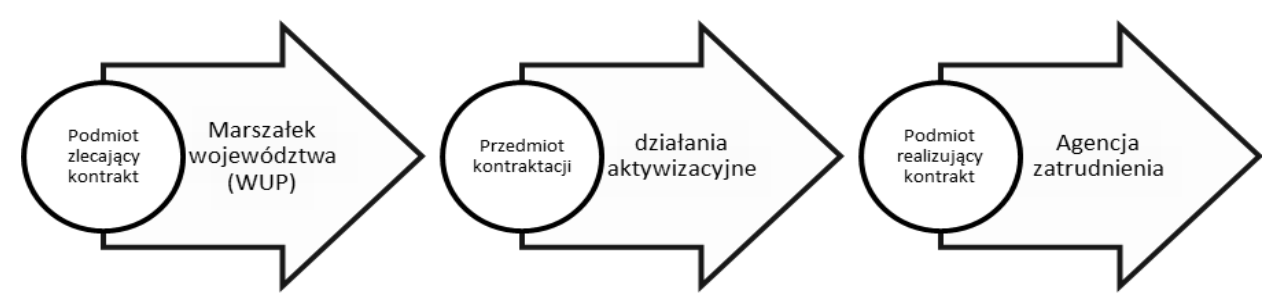

Rysunek 3. Kontraktacja działań aktywizacyjnych

Źródło: opracowanie własne.

Część stała dotyczy wypłaty tzw. pierwszej transzy, stanowiącej wynagrodzenie za zdiagnozowanie sytuacji zawodowej bezrobotnego i ustalenie działań aktywizacyjnych dla niego. Kolejne trzy transze mają charakter motywacyjny, a o ich wypłacie będzie decydować fakt podjęcia przez bezrobotnego pracy oraz okres, przez jaki będzie ona wykonywana. I tak druga transza związana jest z podjęciem pracy przez bezrobotnego i jej wykonywaniem przez okres przynajmniej 14 dni. Wypłata pozostałych transz może być traktowana jako premia, której uruchomienie będzie determinowane okresem aktywności zatrudnieniowej. Jego dolna granica dla III transzy wynosi 90 dni, a dla czwartej $180 \mathrm{dni}$, co ilustruje Rysunek 4. Przedstawione zasady wynagradzania opierają się na trwałości rezultatu kontraktu i wynika z nich, że im dłużej bezrobotny będzie zatrudniony, tym wyższe wynagrodzenie będzie otrzymywać agencja.

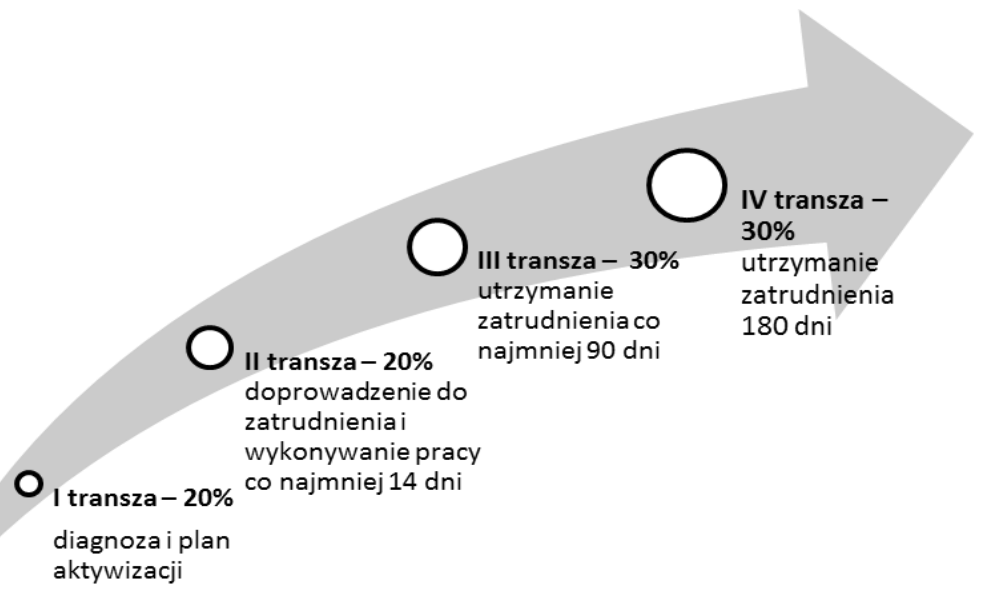

Rysunek 4. Wynagradzanie agencji zatrudnienia

Źródło: opracowanie własne. 
Czy każda agencja zatrudnienia może realizować kontrakt w zakresie działań aktywizacyjnych? Ustawodawca w tym przypadku uwzględnia czas funkcjonowania agencji i certyfikat upoważniający do świadczenia określonego rodzaju usługi. Dopuszczone są do tego procesu te instytucje rynku pracy, które mają udokumentowany roczny okres działalności w zakresie świadczenia usługi pośrednictwa pracy. Wprowadzenie tego typu warunków jest uzasadnione, ma sprzyjać dobrej jakości usług i eliminować z procesu kontraktacji podmioty przypadkowe, niemające odpowiedniego doświadczenia. Posiadanie zatem certyfikatu jest swego rodzaju licencją, wskazującą, że dana agencja zatrudnienia jest wiarygodna, bowiem dysponuje odpowiednimi zasobami, a więc jest zdolna do rozwiązywania określonych problemów. Dotyczyć one będą minimum 200 osób zarejestrowanych jako bezrobotni w jednym powiatowym urzędzie pracy. Należy podkreślić, iż w ramach tej formy kontraktacji agencje będą zajmować się bardzo trudną grupą, tworzoną przez osoby długotrwale bezrobotne, które zaliczono do II lub III profilu pomocy. W takiej sytuacji agencje muszą dysponować odpowiednim potencjałem, który zaangażowany będzie w diagnozowanie pozycji na rynku pracy tak dużej liczby osób, przygotowaniem dla nich odpowiedniego planu działania i umiejscowienia ich u pracodawców funkcjonujących na regionalnym rynku pracy. Realizacja wymienionych działań wymaga od agencji zatrudnienia dysponowania odpowiednią wiedzą, nie tylko na temat bezrobotnych skierowanych przez urzędy pracy, ale także aktualnymi informacjami o firmach i ich zapotrzebowaniu na kapitał ludzki. Ważne jest również, żeby agencja zatrudnienia posiadała wypracowaną sieć kontaktów z przedsiębiorstwami, które mogą okazać się potencjalnymi pracodawcami.

Zlecanie działań aktywizacyjnych przez marszałków województwa agencjom zatrudnienia nie jest traktowane jako powszechne rozwiązanie. O jego wprowadzeniu będzie decydować marszałek województwa na podstawie oceny obsługi instytucjonalnej lokalnych rynków pracy. W tym przypadku uwzględnia się przede wszystkim potencjał kadrowy i organizacyjny PUP, czyli tej instytucji, która jest odpowiedzialna za obsługę lokalnego rynku. Bierze się pod uwagę liczbę bezrobotnych przypadającą na jednego pracownika PUP pełniącego funkcję doradcy klienta i udział tej grupy pracowników w ogólnym zatrudnieniu w urzędzie ${ }^{3}$. Powyższe kryteria wskazują, że kontraktacja jest traktowana jako

${ }^{3}$ Marszałek Województwa może zlecić agencjom zatrudnienia realizację działań aktywizacyjnych w sytuacji kiedy PUP obsługujący lokalny rynek pracy w ostatnim roku (wg stanu na dzień 31 grudnia) cechował jeden z poniższych wskaźników:

- wskaźnik procentowego udziału pracowników pełniących funkcję doradcy klienta był w całkowitym zatrudnieniu niższy niż 5 punktów procentowych poniżej średniego procentowego wskaźnika udziału pracowników uzyskanego we wszystkich powiatowych urzędach pracy,

- wskaźnik liczby bezrobotnych przypadających na jednego pracownika pełniącego funkcję doradcy klienta był wyższy niż 15\% powyżej średniego wskaźnika liczby bezrobotnych uzyskanego we wszystkich powiatowych urzędach pracy. 
działanie komplementarne, mające na celu uzupełnienie, wzmocnienie instytucjonalnej obsługi rynku pracy. Należy podkreślić, iż przy tej formie kontraktacji pojawiają się dwa rodzaje relacji między poszczególnymi instytucjami rynku pracy. Pierwsza oparta jest na współpracy WUP z PUP i fakt ten znajduje odzwierciedlenie w umowie, jaką zawiera marszałek województwa z powiatowym urzędem pracy. Strony umowy w tym przypadku ustalają liczbę i strukturę bezrobotnych, których planują objąć działaniami aktywizacyjnymi oraz uzgadniają warunki i czas realizacji kontraktu. Zadaniem WUP jest wybór wykonawcy usługi, a PUP jest odpowiedzialny za przeprowadzenie rekrutacji bezrobotnych i kieruje ich do agencji zatrudnienia, będącej wykonawcą kontraktu. Druga relacja pojawia się między PSZ/PUP a agencją zatrudnienia i opiera się na komplementarności. Formalne włączenie agencji zatrudnienia w proces obsługi bezrobotnych zarejestrowanych w powiatowym urzędzie pracy oznacza, że kontraktowane działania aktywizacyjne uzupełniają zakres usług świadczonych przez PSZ, ale nie konkurują z nimi. Należy podkreślić, iż bezrobotny skierowany przez PUP do agencji zatrudnienia nie jest pozbawiony swojego statusu. Natomiast przez okres aktywizacji prowadzonej przez realizatora kontraktu pracownicy publicznych służb zatrudnienia nie kierują do niego żadnych form wsparcia mieszczących się w ramach aktywnej polityki rynku pracy przewidzianej ustawą o promocji zatrudnienia.

\section{SZANSE I ZAGROŻENIA, JAKIE TWORZY KONTRAKTACJA DLA RYNKU PRACY}

Przedstawione w tej części artykułu szanse i zagrożenia będą rozpatrywane w kontekście prowadzonej polityki rynku pracy, której narzędziem może być kontraktacja.

Zawieranie kontraktów opartych na współpracy można traktować jako środek zapewniający realizację celów polityki rynku pracy. Kontraktacja oznacza dzielenie się przez organy władzy i administracji publicznej zadaniami oraz odpowiedzialnością z podmiotami prywatnymi i organizacjami pozarządowymi. Podział ten oznacza, iż podejmowana jest współpraca wewnątrz sektorowa i międzysektorowa. W pierwszym przypadku polega ona m.in. na uzgadnianiu zakresów i warunków zlecania działań aktywizacyjnych przez wojewódzkie urzędy pracy z powiatowymi urzędami pracy. Rzecz dotyczy ustalenia liczebności grupy i struktury bezrobotnych objętych tego typu działaniami, okresu realizacji zleconych działań. W drugim opiera się na wyborze przez organy samorządowe niepublicznej instytucji rynku pracy realizującej kontrakt.

Kolejną szansę należy odnieść do zasad kontraktacji, które wskazują, że może być ona traktowana jako środek zapewniający wdrożenie partnerstwa w obszarze 
funkcjonowania rynku pracy, które będzie prowadzone z różnymi instytucjami go obsługującymi. Każdy ze współpracujących podmiotów może mieć inne podejście do projektów aktywizacji zawodowej i dzięki tej różnorodności spojrzeń jest możliwe wypracowanie rozwiązań innowacyjnych i kompleksowych. Kompleksowość przejawia się w zaangażowaniu wielu partnerów, mogących uruchomić wszystkie niezbędne działania, bez których nie ma możliwości uzyskania pożądanego efektu. Warto w tym miejscu nawiązać do doświadczeń innych krajów. Na przykład w Wielkiej Brytanii zastosowano podejście „Black-box” (czarna skrzynka), według którego od agencji zatrudnienia, jako realizatora kontraktu, wymaga się dobrania takiego pakietu działań aktywizacyjnych, który byłby oparty na potrzebach konkretnego uczestnika programu. Agencja samodzielnie podejmowała decyzje o doborze form wsparcia dla klientów. Przytoczone rozwiązanie pozwoliło wyjść poza ramy najczęściej stosowanych działań aktywizacyjnych, co umożliwiło osiągnięcie rezultatu w postaci zatrudnienia osoby objętej kontraktem (Finn 2012).

Z powyższych rozważań wynika, że działania partnerskie, stawiające na podział pracy zgodny z kompetencjami i profilem działania różnych instytucji oraz synergia wynikająca z połączenia wysiłków prowadzą do pomysłów oryginalnych i skutecznych, rozwiązań, które można bezpośrednio odtworzyć lub odpowiednio dopasować do konkretnych warunków. Zatem wspólne rozwiązywanie zadań może przyczynić się do poprawy jakości obsługi podmiotów rynku pracy. Będzie to bowiem możliwe, jak już wspomniano, jeśli zostanie lepiej wykorzystany bogaty potencjał poszczególnych instytucji. Oznacza to, że w praktyce może nastąpić odejście od standardowych narzędzi aktywizacji - jakie wcześniej stosowane były przez PUP - na rzecz nowych rozwiązań, sprawdzonych i dostosowanych do sytuacji oraz problemów określonych grup beneficjentów i potrzeb lokalnego rynku pracy.

Kontraktacja może okazać się kluczowa dla poprawy efektywności funkcjonowania PSZ, które będą mogły skupiać się na tych działaniach i usługach, do realizacji których są najlepiej przygotowane i to pozwoli im rozszerzyć zasięg świadczonych usług. W dłuższej perspektywie może to prowadzić do specjalizacji poszczególnych instytucji w obsłudze określonych grup bezrobotnych. Specjalizacja ta może dotyczyć agencji zatrudnienia lub innych instytucji, np. organizacji pozarządowych, które będą podwykonawcą usług dla dużej agencji realizującej kontrakt. Istotne jest to, że wymienione instytucje mogą znaleźć dla siebie "segmenty niszowe rynku”, np. dotyczące trudnych grup bezrobotnych, a właściwy im profesjonalizm może zwiększyć ich wiarygodność jako instytucji obsługującej nie tylko pracodawców, ale i bezrobotnych. Zjawisko takie wystąpiło w szerokim zakresie w Holandii (Szymańska 2005) i było pozytywnie oceniane przez realizatorów kontraktu i podmioty je zlecające. 
Kontraktacja może przyczynić się do bardziej racjonalnego gospodarowania środkami publicznymi. W tym przypadku doprowadzanie do zatrudnienia określonych grup bezrobotnych powinno być tańsze. Racjonalność ta może być pochodną stosowanych przetargów, konkursów oraz zasad wynagradzania realizatorów kontraktów, które mają charakter bodźcowy. Otóż poziom dochodów z kontraktu będzie determinowany trwałością osiąganych rezultatów. Będą one tym wyższe, im dłużej aktywizowane osoby będą wykonywać pracę. Na niższy poziom kosztów - przedstawianych w ofercie przetargowej (konkursowej) może mieć również wpływ dopraszanie do realizacji kontraktów organizacji pozarządowych. Wynikać to może $\mathrm{z}$ ich misji - należy bowiem podkreślić, iż nie funkcjonują one $\mathrm{w}$ celu generowania zysku, tylko w celu realizacji pewnych zadań społecznych. Ponadto ich przewaga konkurencyjna wobec publicznej i niepublicznej służby zatrudnienia pojawia się $\mathrm{w}$ obszarze diagnozowania, innowacyjności oraz daleko idącej elastyczności (Tyrowicz 2007: 96).

Realizacja zadań publicznych przez instytucje komercyjne może również wpłynąć pozytywnie na klientów, u których w mniejszym stopniu będą pojawiać się postawy roszczeniowe. Jak pokazuje praktyka, instytucjom prywatnym jest łatwiej dyscyplinować klientów/beneficjentów niż publicznym służbom, bowiem one częściej używają sankcji, wymagań i innych bodźców motywujących (Bredgaard, Larsen 2007).

Dokonując oceny rozwiązań, jakie zastosowano w kontraktacji różnych działań w obszarze obsługi rynku pracy, należy uwzględnić również te, które można traktować jako zagrożenia. W przypadku kontraktacji działań aktywizacyjnych za niepokojącą należy uznać liczbę osób przewidzianych do obsługi bezrobotnych, której dolną granicę ustalono na poziomie 200 osób. Wielkość ta wskazuje, że do realizacji kontraktu będą dopuszczone duże agencje zatrudnienia i o dość silnej pozycji finansowej. Istnieje zatem ryzyko eliminowania z rynku mniejszych agencji przez większe, a będzie to możliwe na skutek konkurencji cenowej, bowiem te większe będą oferować korzystniejsze warunki dla realizacji kontraktu. Zjawisko takie zaobserwowano m.in. w Holandii i Australii (Szymańska 2005), w których efekt skali pozwalał dużym firmom rozkładać ryzyko finansowe i oferować niższe ceny niż pozostałym instytucjom przystępującym do przetargów. Duże agencje zatrudnienia będą również mogły łatwiej podejmować decyzje o rozwoju potencjału niezbędnego do sprawnego realizowania zadań objętych kontraktem. Takiej możliwości nie mają małe instytucje, one nie będą także podejmować dodatkowych inwestycji pod kątem przyszłej kontraktacji - ze względu na niepewność kontraktacji działań aktywizacyjnych czy tych dotyczących doprowadzenia bezrobotnych do zatrudnienia.

Należy również podkreślić, iż w Polsce rozmieszczenie różnych agencji zatrudnienia mających uprawnienia do świadczenia usług rynku pracy jest zróżnicowane przestrzennie. Na tych terenach, na których występuje najwyższa stopa 
bezrobocia jest ich stosunkowo mało w porównaniu do rynków pracy o mniejszym natężeniu dezaktywizacji zawodowej, a kontraktacja może te różnice jeszcze bardziej zaostrzyć.

Analizując proces kontraktacji, należy zauważyć jej fakultatywny charakter i pojawiające się kolejne zagrożenia. Uwaga ta nie oznacza, że kontraktacja powinna być obligatoryjna, na pewno nie byłoby celowe jej wprowadzenie w sytuacji, kiedy PSZ radzą sobie z aktywizacją osób bezrobotnych i jakość ich usług jest pozytywnie oceniana zarówno przez klientów indywidualnych, jak i instytucjonalnych. Takich jednak przykładów dotyczących lokalnych rynków pracy w Polsce jest mało. Problem, jaki pojawia się w tym przypadku, wynika z braku określenia przez ustawodawcę częstotliwości kontraktacji. Decyzje o zlecaniu usług lub działań aktywizacyjnych podejmuje marszałek województwa lub starosta w zależności od przedmiotu kontraktu. Sytuacja ta może oznaczać, iż na niektórych lokalnych rynkach pracy kontraktacja nie będzie w ogóle stosowana lub bardzo rzadko będzie przeprowadzana. W konsekwencji może to doprowadzić do zubożenia, zawężenia rynku tych usług. Określonym grupom instytucji trudno będzie bowiem utrzymać się na rynku, jeśli nie będą miały pewności regularnego ubiegania się o ten rodzaj zleceń. Należy również podkreślić czas, na jaki kontrakt jest zawierany, a w Polsce wynosi on jeden rok, co może również zniechęcać określone instytucje do ubiegania się o jego realizację. W Holandii kontrakty mogą być realizowane do dwóch lat (de Koning 2004), a Wielkiej Brytanii do siedmiu (Carter 2015). Wydłużenie okresu ich realizacji ma zachęcić wykonawców do inwestowania w kapitał ludzki, rzeczowy, organizacyjny w celu zapewnienia wysokiej jakości usług aktywizacyjnych. Ponadto dopuszcza się opcję wydłużania kontraktów ze sprawdzonymi wykonawcami, uzyskującymi wysokie rezultaty. Rozwiązanie to jest $\mathrm{z}$ jednej strony traktowane jako bodziec dla wykonawców, a z drugiej jako sposób na ograniczanie kosztów transakcyjnych.

Doświadczenia z innych krajów wskazują na niebezpieczeństwo wystąpienia zjawiska creamingu, które może pojawić się w sytuacji, kiedy te same rodzaje usług są prowadzone przez PSZ i instytucje niepubliczne. Oznaczać to może w przypadku usługi pośrednictwa pracy, którą mogą wykonywać urzędy pracy i agencje zatrudnienia, że nastąpi przekierowanie do sektora niepublicznego tych bezrobotnych, którzy są bardziej oddaleni od rynku pracy, u których występują cechy wskazujące na niższą ich zatrudnialność. Tego typu praktyka jest możliwa do wprowadzenia, bowiem to PUP-y z bazy osób zarejestrowanych w urzędzie dokonują rekrutacji, selekcji bezrobotnych, których obsługą zajmować się będą instytucje zewnętrzne w ramach podpisanych kontraktów. Dlatego ważne jest zapewnienie podziału usług między instytucje rynku pracy, co powinno eliminować świadczenie tych samych usług przez urzędy pracy i realizatorów kon- 
traktu dla tej samej grupy beneficjentów, np. długotrwale bezrobotnych, niepełnosprawnych, osób powyżej 50 roku życia.

Ponadto w ramach już realizowanego kontraktu może pojawić się efekt parkowania, oznaczający, że kontraktorzy będą przyjmować do programu osoby trudne do aktywizacji tylko po to, aby otrzymać wynagrodzenie w ramach pierwszej transzy. Po jej otrzymaniu nie będą oferować żadnego wsparcia, wiedząc, że szanse na ich zatrudnienie są niewielkie. Dlatego w walce $\mathrm{z}$ efektem parkowania można zastosować zróżnicowane stawki wynagrodzeń dla realizatorów kontraktów, uwzględniając stopień oddalenia od rynku pracy bezrobotnych. I tak w Wielkiej Brytanii o wiele wyższe opłaty stosowano za aktywizację byłych więźniów w porównaniu do osób młodych (Carter 2015).

$\mathrm{Z}$ punku widzenia przedmiotu kontraktowania rozwiązania prawne w tym obszarze nie tworzą spójnego logicznego modelu. Jak zostało to szerzej przedstawione $\mathrm{w}$ artykule, istnieje pewna rozbieżność pomiędzy przepisami dotyczącymi kontraktowania działań aktywizacyjnych, a tymi odnoszącymi się do doprowadzenia osób będących w szczególnej sytuacji do zatrudnienia. W jednym i drugim przypadku mamy do czynienia z tym samym celem, mimo iż przedmiot jest inaczej zdefiniowany przez ustawodawcę - chodzi tu o zatrudnienie osoby bezrobotnej (długotrwale przebywającej w zasobie bezrobotnych) i utrzymanie przez nią pracy przez okres 6 miesięcy. Występują jednak duże różnice w zasadach wynagradzania agencji zatrudnienia za zrealizowany kontrakt. Regulowanie zlecania przez PSZ różnych działań instytucjom zewnętrznym na podstawie trzech różnych artykułów ustawy o promocji zatrudnienia, może wprowadzać pewien chaos organizacyjny, sugerować preferencje pewnych przedmiotów kontraktacji i powodować, że niektóre instytucje rynku pracy nie będą pojawiać w relacjach z PSZ.

Jako zagrożenie należy również uznać brak systemowego rozwiązania w obszarze zlecania usług i działań aktywizacyjnych. Problem, który się tu ujawnia, dotyczy uporządkowania i ustalenia kryteriów ogólnych, zunifikowanych, a więc uwzględnianych we wszystkich przetargach (ale nie może nim być tylko najniższa cena) i tych zmiennych, których kształt wynikałby z sytuacji, jaka jest na lokalnym rynku pracy. Ustalenie kryteriów i nadanie im względnie trwałego charakteru jest istotne dla zachowania zasady przejrzystości procedury przetargowej, co jest ważne dla jakości regionalnej czy lokalnej polityki rynku pracy.

Wprowadzenie kryteriów efektywnościowych do kontraktacji w przypadku, kiedy jej przedmiotem jest doprowadzenie do zatrudnienia szczególnej grupy beneficjentów lub zlecanie działań aktywizacyjnych, może z jednej strony o czym wspomniano wcześniej - przynosić korzyści, ale z drugiej mogą pojawić się pewne niebezpieczeństwa. Jako zagrożenie należy uznać możliwość częstszego wykorzystania przez realizatorów kontraktów działań, których efekty będą oznaczać szybkie doprowadzenie bezrobotnych do zasobu pracujących i krótko- 
trwałe ich zatrudnienie. Oznaczać to może eliminowanie z programów aktywizacyjnych instrumentów kosztownych, których efekty nie pojawiają się w krótkim okresie, tylko w dhuższym (jak np. szkolenia). Stosowane zatem przez realizatora kontraktu instrumenty czy działania mogą okazać się skuteczne doraźnie, ale nie sprawdzą się w dłuższym przedziale czasu , a problem ten może być początkowo niedostrzegany, bowiem urząd pracy jako usługodawca jest nieobecny w kontrakcie, a tym samym nie ponosi on żadnej odpowiedzialności wobec beneficjentów. W celu wyeliminowania tego typu praktyk istotne jest wypracowanie systemu pozwalającego na monitorowanie przedmiotu kontraktu i sytuacji osób, które będą korzystać ze wsparcia określonego w kontrakcie. Niestety obecnie system taki nie funkcjonuje.

\section{PODSUMOWANIE}

Przedstawiony model kontraktacji nawiązuje do koncepcji wielosektorowej polityki społecznej. Źródeł jej można poszukiwać w pracach L.M. Salamona (Salamon 1981, 2000), który przedstawił w nich założenia idei partnerstw społecznych. Miały one stanowić alternatywę dla teorii zawodności państwa i teorii zawodności rynku. Według badacza partnerstwo międzysektorowe to współpraca między rządem a podmiotami pozarządowymi. Zadaniem rządu jest dostarczanie funduszy i propagowanie polityki usług społecznych, natomiast rolą organizacji pozarządowych, biznesowych jest świadczenie tych usług dla określonych grup beneficjentów. Uznał on, że współpraca międzysektorowa jest najbardziej efektywnym sposobem realizacji zadań publicznych. Sposoby współpracy między partnerami mogą być oparte m.in. na kulturze kontraktu, która ma cechy quasi-rynkowe. Polega ona na zawieraniu przez administrację publiczną kontraktu, na realizacji zadań publicznych z podmiotami sektora biznesowego lub społecznego Rozwój kultury kontraktu w Europie związany był z kryzysem państwa opiekuńczego i prorynkowymi reformami sfery socjalnej. Reformy te zostały zapoczątkowane w Wielkiej Brytanii w latach 80. XX wieku i rozpowszechnione na kontynencie europejskim w latach 90.

Wprowadzone w Polsce w 2014 r. zmiany w instytucjonalnej obsłudze rynku pracy nawiązują do kultury kontraktu. Mają one upowszechnić kontraktację, w założeniach dają podstawy do rozszerzenia działań podejmowanych w sferze społecznej w wyniku połączenia aktywności administracji publicznej i podmiotów niepublicznych, a także określenia ram dla ich działalności w tworzeniu oraz świadczeniu usług doprowadzających do zatrudnienia. Dowodzi to poszerzenia procesów decentralizacyjnych w obszarze rynku pracy i daje możliwości do kreowania modelu lokalnej polityki opartej na działaniu wielu podmiotów. Powinno to skutkować rozłożeniem odpowiedzialności za obsługę rynku pracy 
między różne instytucje, które dysponują określonym potencjałem kadrowym, technicznym i finansowym.

Analizowany model kontraktacji jest odpowiedzią na nowe wyzwania wobec polityki rynku pracy i na wprowadzenie wymogu racjonalności podejmowanych działań w obszarze aktywizacji rynku pracy. Zaimplementowanie bodźców do sytemu wynagradzania podmiotów zewnętrznych może nie tylko prowadzić do efektywnego gospodarowania środkami publicznymi, ale i implikować korzyści dla podstawowych podmiotów rynku pracy. Po pierwsze przyspieszyć wejście wielu bezrobotnych na rynek pracy, co zmniejszy straty w ich kapitale ludzkim, a po drugie ograniczyć straty dla przedsiębiorców mających problemy $\mathrm{z}$ realizacją swojego popytu na pracę.

Wdrażany model w obecnym kształcie nie został wcześniej przetestowany, a to może oznaczać, iż pojawiać się będą pewne problemy wymagające interwencji ze strony organów publicznych. Jednak diagnozowanie ich wymaga wypracowania narzędzia $\mathrm{w}$ formie monitoringu, pozwalającego na stałą obserwację działań podejmowanych przez instytucje zewnętrzne, realizujące kontrakt. Jak pokazują doświadczenia międzynarodowe, w wyniku obserwacji zarządzający kontraktowaniem podnoszą swoje umiejętności, które umożliwiają im wykluczenie z rynku słabych realizatorów kontraktów i doskonalenie zarządzania rezultatami (Finn 2011). Przygotowanie i wdrożenie monitoringu jest zatem niezbędne $\mathrm{w}$ celu zapewnia dobrego sterowania rynkiem pracy zarówno na poziomie kraju, regionu, jak i powiatu. Monitoring jako narzędzie zarządzania może zapewnić przejrzystość procesu kontraktowania.

Analizowane w opracowaniu rozwiązania prawne tworzą model kontraktacji, który ma charakter otwarty, a więc kształt jego będzie ewoluował. Obecny jego stan daje podstawy do tworzenia w Polsce rynku usług prowadzących bezrobotnych do zatrudnienia. Funkcjonować na nim będą prywatni dostawcy usług, konkurujący między sobą poprzez udział w publicznym przetargu czy konkursie. Implikować to powinno lepsze jakościowo i tańsze usługi zatrudnienia niż miało to miejsce przed upowszechnieniem kontraktacji. W podejmowanych działaniach na rzecz osób bezrobotnych częściej powinny pojawiać się te o charakterze innowacyjnym, które usprawnią instytucjonalną obsługę rynku pracy. Dla zapewnienia dobrych jakościowo działań niezbędne jest jednak ustalenie pewnych wskaźników pomiaru efektywności działań aktywizacyjnych, aby te o charakterze ekonomicznym (np. oszczędności dla zleceniodawców) nie były podstawowym kryterium oceny składanych ofert. Wskaźniki te powinny również uwzględniać specyfikę poszczególnych lokalnych, regionalnych rynków pracy. Jeśli tak się nie stanie, to kontraktowanie w obszarze aktywizacji rynku pracy okaże się sposobem na poszukiwanie oszczędności budżetowych, a konkursy sprowadzać się będą do wyboru najtańszych projektów. 


\section{BIBLIOGRAFIA}

Baron-Wiaterek M. (2008), Instytucjonalno-prawne aspekty rynku pracy i promocji zatrudnienia, IPiSS, Warszawa.

Błędowski P. (2008), Efektywność usług i instrumentów rynku pracy stużacych podnoszeniu kwalifikacji bezrobotnych w Polsce $i$ wybranych krajach Unii Europejskiej, Ministerstwo Pracy i Polityki Społecznej, Warszawa.

Bredgaard T., Larsen F. (2007), Implementing public employment policy: what happens when nonpublic agencies take over? "International Journal of Sociology and Social Policy", vol. 27, $\mathrm{nr} 7 / 8$.

Carter E., Whitworth A. (2015), Creaming and parking in quasi-marketised welfare-to-work schemes: Designed out of or designed in to the UK work programme?, "Journal of Social Policy, vol. 44, nr 2.

De Koning J. (2004), The reform of the Dutch Public Employment Service, SEOR, Rotterdam.

Grewiński M. (2009), Wielosektorowa polityka społeczna. O przeobrażeniu państwa opiekuńczego, Wydawnictwo Wyższej Szkoły Pedagogicznej TWP, Warszawa.

Finn D. (2011), Sub-contracting in Public Employment Services. Review of Research Findings on Recent Trends and Business, The European Commission, DG Employment Social Affairs and Inclusion, Bruksela.

Finn D. (2012), Subcontracting in PES. The Design and Delivery of Outcome Based and Black Box Contracts. The European Commission, DG Employment Social Affairs and Inclusion, Bruksela.

Informacje o stanie zatrudnienia w WUP i PUP; http://www.mpips.gov.pl/analizy-i-raporty/raporty -sprawozdania/rynek-pracy/stan-zatrudnienia/rok/.

Jak zniszczono poradnictwo zawodowe w urzędach pracy (2015), „Doradca Zawodowy” nr 2 (31).

Krzyszkowski J., Marks M. (2006), Partnerstwo międzysektorowe na rzecz aktywizacji klientów środowiskowej pomocy społecznej. Badania w województwie łódzkim, [w:] Twoja wiedza Twój sukces. Edycja 2005. Edukacja kluczem do przyszłości, Ochotnicze Hufce Pracy, Komenda Główna, Warszawa.

Kukulak-Dolata I, Pichla J. (2007), Rola publicznych stużb zatrudnienia i agencji zatrudnienia na rynku pracy, IPiSS, Warszawa.

Salamon L.M. (1981), Rethinking Public Management: Third Party Government and the Public Action, Public Policy 29.

Salamon L.M., (2000), The New Governance and the Tools of Public Action: An Introduction, "Fordham Urban Law Journal", vol. 28.

Rymsza M. (2013), Aktywizacja w polityce społecznej. W stronę rekonstrukcji europejskich welfare states?, Wydawnictwo Instytutu Filozofii i Socjologii PAN, Warszawa.

Stownik wyrazów obcych (1995), PWN, Warszawa.

Szymańska A. (2005), Raport dotyczacy organizacji i działania rynku ustug zatrudnienia w warunkach wolnej konkurencji oraz doświadczeń niekomercyjnych organizacji pozarzadowych działajacych na tym rynku w poszczególnych krajach (Holandia, Australia, Dania, Wielka Brytania, Stany Zjednoczone), FISE, Warszawa.

The Service Model of Public Employment Service to Support the Fight Against Long-Term Unemployment, (2000), "Working Paper of the Commission Services", nr 22.

Tyrowicz J. (2007), Ewaluacja i efektywność programów społecznych w Polsce, [w:] M. Grewiński, J. Tyrowicz (red.), Aktywizacja, partnerstwo, partycypacja - o odpowiedzialnej polityce społecznej, Mazowieckie Centrum Polityki Społecznej, Warszawa.

Ustawa o działalności pożytku publicznego $i$ wolontariacie z dnia 24 kwietnia 2003 r. (Dz.U. 2010, 234.1536).

Ustawa o zmianie ustawy o promocji zatrudnienia $i$ instytucjach rynku pracy oraz niektórych innych ustaw z dnia 14 marca 2014 r. (Dz.U. 2014, poz. 598). 
Ustawa prawo zamówień publicznych z 29 stycznia 2004 r. (Dz.U. 2014, 12320).

Wóycicka I., Sztandar-Sztanderska K., Zielińska M. (2008), Klienci powiatowych urzędów pracy, [w:] Analiza funkcjonowania urzędów pracy po ich właczeniu do administracji samorządowej, Ministerstwo Pracy i Polityki Społecznej. Departament Rynku Pracy, Warszawa.

\author{
Iwona Kukulak-Dolata
}

\title{
THE ROLE OF SUBCONTRACTING IN ACTIVATING OF LOCAL LABOUR MARKET
}

\begin{abstract}
This article explains the meaning of subcontracting in activation of local labour markets in Poland. It was indicated what positive and negative results, subcontracting brings for handling labour market. Fundamentals of this work consist of critical study of legal acts regulating subcontracting in labour market and study of an available literature. Described model of subcontracting should be considered as open because it is going to evolve on account of how it affects professional activation of unemployed.

Keywords: subcontracting, public employment services, private employment agencies, labour market.
\end{abstract}

